\title{
IMPLEMENTASI SUPERVISI KELEMBAGAAN \\ DI MI NAJATUS SALIKIN KEDUNGSARI TAROKAN KABUPATEN KEDIRI
}

\author{
Moh. Hilmy Muqowimul Adab \\ Program Pascasarjana Institute Agama Islam Tribakti Kediri
}

\begin{abstract}
Abstrak
Pengawasan mutu pendidikan yang diemban oleh pengawas satuan pendidikan harus terus digalakkan seiring dengan perkembangan teknologi dan mutu pendidikan yang kompetitif. Pengawasan bisa dilakukan dengan pengamatan secara intensif terhadap kegiatan utama dalam lembaga pendidikan yang kemudian ditindak lanjuti dengan pemberian feed back.

Permasalahan yang peneliti ajukan antara lain: 1. Bagaimanakah pelaksanaan supervisi kelembagaan di MI Najatus Salikin Kedungsari Tarokan Kediri, 2. Bagaimana hasil dari pelaksanaan supervisi kelembagaan di MI Najatus Salikin Kedungsari Tarokan Kediri, 3. Apa saja yang menjadi faktor pendukung dan penghambat dalam melaksanakan supervisi kelembagaan di MI Najatus Salikin Kedungsari Tarokan Kediri.

Jenis penelitian ini adalah kualitatif, sebagaimana arahan jenis penelitian kualitatif, maka data yang terkumpul kemudian dianalisis berdasar teori - teori yang diketemukan guna menarik sebuah kesimpulan yang sesuai dengan maksud diadakannya suatu penelitian tersebut.

Akhirnya, penelitian dapat disimpulkan 1. Kepala Madrasah Ibtidaiyah Najatus Salikin telah melaksanakan kegiatan supervisi kelembagaan dengan baik sebagai supervisor pada lembaga tersebut, 2. Hasil dari pelaksanaan kegiatan supervisi kelembagaan ini berdampak pada peningkatan komunikasi antar personal dan staf serta para pengurus komite madrasah yang berujung pada perbaikan dan peningkatan kinerja masing-masing lini, 3. Faktor yang mempengaruhi pelaksanaan supervisi kelembagaan yaitu: kebijakan yang diberlakukan kepala sekolah, dan tingkat interaksi serta komunikasi baik antara kepala sekolah dengan bawahannya maupun antara guru dengan peserta didiknya.
\end{abstract}

Kata Kunci: Implementasi, Supervisi Kelembagaan

\section{Konteks Penelitian}

Pengawasan mutu pendidikan yang diemban oleh pengawas satuan pendidikan harus terus digalakkan seiring dengan perkembangan teknologi dan mutu pendidikan yang kompetitif. Pengawasan bisa dilakukan dengan pengamatan secara intensif terhadap kegiatan utama dalam lembaga pendidikan yang kemudian ditindak lanjuti dengan pemberian feed back.

Dalam usaha meningkatkan kualitas sumberdaya pendidkan, guru merupakan komponen sumber daya manusia yang harus dibina dan dikembangkan terus-menerus. Pengembangan profesi guru dilaksanakan melalui program pendidikan. Potensi sumber daya guru itu perlu di tumbuhkembangkan agar dapat melakukan fungsinya secara potensial. Selain itu, pengaruh perubahan yang serbacepat mendorong para guru untuk terus belajar menyesuaikan diri dengan perkembangan ilmu pengetahuan dan teknologi serta mobilitas masyarakat.

Terkait hal itulah, posisi supervisor (pengawas/kepala) sekolah menjadi menjadi penting, dengan menjalankan fungsi, 
tugas dan tanggung jawabnya diharapkan mampu memberikan bantuan dan terobosan terhadap permasalahan-permasalahan pendidikan umumnya, dan para guru pada khususnya agar dapat memperbaiki kinerja dan proses pembelajaran. Depdiknas merumuskan supervisi sebagai pembinaan yang diberikan kepada seluruh staf sekolah agar dapat meningkatkan kemampuan untuk mengembangkan situasi belajar mengajar yang lebih baik. ${ }^{1}$

Dari prinsip-prinsip supervisi dapat diketahui maknanya bahwa supervisi sebagai suatu kegiatan untuk dilakukan terencana, rutin, berkelanjutan yang dilakukan oleh kepala sekolah, yang menggunakan data dari hasil pergamatan atau observasi nyata menggunakan instrumen yang dapat memberikan informasi yang sebenarnya, sama sekali bukan hasil pelajaran pribadi supervisor.

Berdasar latar belakang tersebut, penulis berkeinginan mengadakan penelitian dengan mengangkat judul Implementasi Supervisi Kelembagaan di MI Najatus Salikin Kedungsari Tarokan Kediri.

\section{Fokus Penelitian}

Fokus penelitian ini pada prinsipnya menganalisis tentang cara yang ditempuh superviser dalam melaksanakan supervise di lembaga sehingga hasilnya secara nyata dapat terukur. Fokus penelitian ini kemudian dirinci menjadi dua fokus yakni 1) bagaimanakah pelaksanaan supervisi kelembagaan di MI najatus salikin kedungsari tarokan Kediri, 2) bagaimana hasil dari pelaksanaan supervisi kelembagaan di MI najatus salikin kedungsari tarokan Kediri, dan 3) apa saja yang menjadi faktor pendukung dan penghambat dalam melaksanakan supervisi kelembagaan di MI najatus salikin kedungsari tarokan kediri?

\section{Kerangkas Teori}

\section{Supervisi Kelembagaan}

Dalam Carter Good's Dictionary of Education seperti dikutib oleh oteng sutisna

1 ibid, hlm 7-8.
(1983), supervisi didefinisikan sebagai:

Segala sesuatu dari para pejabat sekolah yang diangkat yang diarahkan kepada penyediaan kepemimpinan bagi para guru dan tenaga kependidikan dalam perbaikan pengajaran, melihat stimulasi pertumbuhan profesional dan perkembangan dari para guru, seleksi dan revisi tujuan-tujuan pendidikan, bahan pengajaran, dan metode-metode mengajar, dan evaluasi pengajaran.

Batasan tersebut tampaknya masih kabur dan agak membingungkan, namun arahnya sudah jelas, yaitu tertuju pada pengajaran.

Supervisor itu sendiri berperan guna memberi support, membantu assisting, dan mengikut sertakan shearing. Yakni menciptakan suasana sedemikian rupa sehingga guru-guru merasa aman dan bebas dalam mengembangkan potensi dan daya kreasinya dengan penuh tanggungjawab.

Memang dalam pembahasan sekarang ini masih ada yang memakai kata atasan dan bawahan akan tetapi ini hanya untuk memudahkan orang dalam menggambarkan pola hubungan dalam posisi masing-masing antara supervisor dengan yang disupervisi, bukan untuk pemaknaan secara subtansial. ${ }^{2}$

\section{Fungsi Supervisi}

Berdasar dari pengertian tersebut diatas, maka fungsi supervisi yang penting untuk diketahui oleh pimpinan pendidikan termasuk kepala sekolah, yaitu: Dalam bidang kepemimpinan. a) Menyusun rencana dan mengawasi bersama. b) Mengikutsertakan anggota-anggota kelompok (para guru dan pegawai) dalam berbagai kegiatan. c) Memberikan bantuan kepada anggota kelompok dalam menghadapi dan memecahkan persoalan-persoalan. d) Membagi dan mendelegasikan wewenang serta tanggung jawab kepada anggota kelompok sesuai dengan fungsi dan kemampuan masing-masing.

Dalam hubungan kemanusiaan. a) Memanfaatkan kekeliruan atau kesalahan

2 Ratal, Wirjasantosa, (1984) Supervisi Pendidikan Olah Raga. UL-Press. Jakarta, HIm. 89. 
yang dialami untuk dijadikan pelajaran guna perbaikan selanjutnya. b) Mengarahkan anggota kelompok pada sikap-sikap yang demokratis.c) Menghilangkan rasa saling mencurigai antar sesama anggota kelompok. Dalam pembinaan proses kelompok: a) Mengenal masing-masing diri pribadi anggota kelompok, baik kelemahan maupun kemampuan masing-masing. b) Memupuk sikap dan kesediaan tolongmenolong. c) Bertindak bijaksana dalam menyelesaikan pertentangan atau perselisihan pendapat diantara anggota kelompok. Dalam bidang administrasi personel: a) Memilih personel yang memiliki syarat-syarat dan kecakapan yang diperlukan untuk menangani suatu pekerjaan. b) Menempatkan personel pada tempat dan tugas yang sesuai dengan kecakapan dan kemampuan yang dimiliki. c) Mengusahakan susunan kerja yang menyenangkan dan meningkatkan daya kerja serta hasil maksimal.

Dalam bidang evaluasi: a) Menguasai dan memiliki ukuran-ukuran yang akan digunakan sebagai kriteria penilaian. b) Menguasai teknikteknik pengumpulan data untuk memperoleh data yang lengkap, benar, dapat diolah menurut norma yang ada. c) Menafsirkan dan menyimpulkan hasil-hasil penilaian sehingga mendapat gambaran tentang kemungkinan untuk mengadakan perbaikan kedepan. ${ }^{3}$

Sementara itu dibagian lain, Gregorio (1966) mengemukakan bahwa lima fungsi utama supervisi antara lain berperan sebagai inspeksi, penelitian, pelatihan, bimbingan dan penilaian.

\section{Tujuan Supervisi}

Tujuan umum supervisi adalah memberikan bantuan teknis dan bimbingan kepada guru dan staf sekolah yang lain agar personil tersebut mampu meningkatkan kualitas kinerjanya, terutama dalam melaksanakan tugas, yaitu melaksanakan proses pembelajaran. Selanjutnya apabila kualitas kinerja guru dan staf sudah meningkat, demikian pula mutu pembelajarannya, maka

3 Ngalim purwanto, (1987) Administrasi Dan Supervisi Pendidikan, PT Remaja Rosdakarya, Bandung, 86-87. diharapkan prestasi belajar juga meningkat. Pemberian bantuan pembinaan dan bimbingan tersebut dapat bersifat langsung ataupun tidak langsung kepada guru yang bersangkutan.

Lebih ringkas tentang tujuan supervisi adalah untuk mengembangkan dan mencapai proses belajar mengajar yang relevan dan efektif melalui peningkatan kemampuan guru. ${ }^{4} \mathrm{Hal}$ ini dapat dijabarkan untuk meningkatkan kinerja siswa sekolah dalam perannya sebagai peserta didik yang belajar dengan semangat tinggi, agar dapat mencapai prestasi belajar secara optimal. Meningkatkan mutu kinerja guru sehingga berhasil membantu dan membimbing siswa mencapai prestasi belajar dan pribadi sebagaimana diharapkan.

\section{Prinsip Supervisi Pendidikan}

Supervisi pendidikan mempunyai prinsipprinsip sebagai aktivitas

pembinaan guru, antara lain hendaknya supervisi dilaksanakan secara:

Ilmiah (scientific) yang berarti harus sistematis yaitu dilaksanakan secara teratur, berprogram dan kontinyu, obyektif yaitu berdasar pada data dan informasi, menggunakan instrumen yang dapat memberi data atau informasi sebagai bahan untuk mengadakan penilaian terhadap proses pembelajaran.

Demokratis, yaitu menjunjung tinggi asas musyawarah, memiliki jiwa kekeluargaan yang kuat serta sanggup menerima pendapat orang lain.

Kooperatif, yaitu mengembangkan usaha bersama untuk menciptakan situasi pembelajaran yang lebih baik.

Konstruktif dan kreatif, yaitu membina inisiatif guru serta mendorongnya untuk akif dalam menciptakan situasi pembelajaran yang lebih baik. $^{5}$

4 Oemar Hamalik,(2008), Manajemen Pengembangan Kurikulum, Bandung: Remaja Rosdakarya, hal. 194.

5 Kisbiyanto, (2008) Supervisi Pendidikan, STAIN Kudus, Kudus, hlm 10. 


\section{Bentuk Proses Supervisi}

Ada lima bentuk proses supervisi yang penting untuk kita ketahui, yaitu: 1) Supervisi korektif, adalah suatu bentuk bimbingan dan bantuan yang berkaitan dengan upaya perbaikan (koreksi); 2) Supervisi Preventif, kegiatan bimbingan dan bantuan dalam rangka mengantisipasi suatu dampak (bisa kebijakan, ataupun kondisi) agar efektivitas pencapaian tujuan bisa dicapai. 3) Supervisi Konstruktif, adalah suatu kegiatan supervisi yang dimaksudkan untuk mengembangkan suatu operasionalisasi pencapaian tujuan pendidikan menjadi lebih baik dan lengkap. 4) Supervisi Kooperatif, adalah bentuk supervisi yang dilakukan bersama antara supervisor dengan guru. Satu sama lain memiliki insiatif untuk memperbaiki proses, meningkatkan kualitas, dan produktivitas, dan 5) Supervisi Kreatif, bentuk supervisi yang mencoba mengembangkan hal yang betul-betul baru, inovatif. ${ }^{6}$

Sementara itu langkah-langkah supervise dapat dijalankan melalui Pertemuan pendahuluan yakni menciptakan suasana kekeluargaan yang intim antara guru dengan supervisor agar komunikasi selama kegiatan dapat berlangsung secara efektif, membuat kesepakatan antara guru dengan supervisor tentang aspek proses belajar mengajar yang akan dikembangkan dan ditingkatkan, perencanaan oleh guru dan supervisor. Yaitu membuat perencanaan pelaksanaan observasi secara bersama sama. Pelaksanaan latihan mengajar dan observasi

Pada waktu ini guru melaksanakan kegiatan mengajar dan supervisor melakukan pengamatan secara cermat, dengan menggunakan instrumen observasi. Mengadakan analisis data. Dalam langkah ini supervisor mengajak guru untuk mendiskusikan apa yang telah dilaksanakan oleh guru waktu mengajar. Diskusi memberikan umpan balik. Kegiatan ini bertujuan untuk memberikan umpan balik yang dilakukan oleh supervisor kepada guru yang sedang berlatih mengajar

6 Lia yuliana, http://www.infodiknas.com/pelaksanaansupervisi-pendidikan-oleh-kepala-sekolah-terhadapguru.html, diakses 23-05-2016. meningkatkan keterampilannya. Pemberian umpan balik harus dilakukan dengan segera dan obyektif. ${ }^{7}$

\section{Paparan Data}

Implementasi Supervisi Kelembagaan Di MI Najatus Salikin Kedungsari Kecamatan Tarokan Kebupaten Kediri.

Implementasi kelembagaan di MI Najatus Salihin melalui beberpa tahap antara lain:

\section{Penyusunan dan Pengembangan Kurikulum.}

Secara umum, penyusunan dan pengembangan kurikulum di MI Najatus Salikin sudah tepat dan sesuai, karena sebagai pengembang kurikulum, guru sepenuhnya dapat menyusun kurikulum sesuai dengan karakteristik, misi dan visi sekolah/madrasah, serta disesuaikan dengan pengalaman belajar yang diperlukan peserta didik. Dalam pengembangan kurikulum, sepenuhnya diserahkan kepada masing-masing satuan pendidikan, karena itu kurikulum yang berkembang dapat berbeda antara lembaga yang satu dengan lembaga yang lainnya.

KTSP dikembangkan dengan mengacu pada standar isi (SI) dan standar kompetensi lulusan (SKL), berpedoman pada panduan penyusunan kurikulum yang disusun oleh BSNP, serta memperhatikan pertimbangan komite madrasah. ${ }^{8}$

Selain itu menurut oemar hamalik dalam joko susilo membagi prinsip - prinsip pengembangan kurikulum kedalam beberapa macam antara lain:

a. Prinsip berorientasi pada tujuan.

Pengembangan kurikulum diarahkan untuk mencapai tujuan tertentu yang bermuara pada tujuan pendidikan nasional. Tujuan kurikulum merupakan penjabaran dan upaya untuk mencapai tujuan satuan dan jenjang

7 http://staff.uny.ac.id/sites/default/files/10\%20Supervisi\%20Pendidikan.pdf, diakses tanggal 07-04-2016.

8 Nik Haryati (2011), Pengembangan Kurikulum Penddikan Agama Islam, Alfabeta, Bandung, hlm 45. 
pendidikan tertentu.

\section{b. Prinsip relevansi (kesesuaian).}

Pengembangan kurikulum yang meliputi tujuan, isi dan sistem penyampaiannya harus relevan (sesuai) dengan kebutuhan dan keadaan masyarakat, tingkat kebutuhan siswa, serta serasi dengan perkembangan ilmu pengetahuan dan teknologi.

\section{c. Prinsip kontinuitas (berkesinambungan).}

Kurikulum disusun secara berkesinambungan, artinya bagian - bagian, aspek - aspek, materi dan bahan kajian disusun secara berurutan, tidak terlepas - lepas, melainkan satu sama lain memiliki hubungan fungsional yang bermakna, sesuai dengan jenjang pendidikan, dan tingkat perkembangan siswa. Dengan prinsip ini dapat mempermudah guru dan siswa dalam melaksanakan pembelajaran.

\section{d. Prinsip keterpaduan.}

Kurikulum dirancang dan dilaksanakan berdasarkan prinsip keterpaduan. Perencanaan terpadu bertitik tolak dari masalah atau topik dan konsistensi antar unsur - unsurnya. Pelaksanaan ini melibatkan semua pihak, baik di lingkungan sekolah maupun pada tingkat inter-sektoral. Dengan keterpaduan ini diharapkan dapat terbentuknya pribadi dan utuh. Disamping itu juga dilaksanakan keterpaduan dalam proses pembelajaran, baik dalam interaksi antara siswa dan guru maupun antara teori dan praktik. ${ }^{9}$

\section{Penyelenggaraan Kegiatan Belajar Mengajar di MI Najatus Salikin.}

Pelaksanaan pembelajaran erat kaitannya dengan penciptaan lingkungan yang memungkinkan siswa belajar secara aktif, pengembangan aspek pengetahuan, sikap dan keterampilan peserta didik, penyesuaian

9 M. Joko Susilo (2007), Kurikulum Tingkat Satuan Pendidikan: Manajemen Pelaksanaan Dan Kesiapan Sekolah Menyongsongnya, Pustaka Pelajar, Yogyakarta, hlm 109 - 112. dengan rencana kegiatan dan pengelolaan kelas. Proses belajar mengajar harus berorientasi kepada lingkungan tanpa mengabaikan prinsipprinsip kepribadian, dan hasil pendidikan harus bermanfaat dan dimanfaatkan oleh masyarakat. Kegiatan belajar mengajar dikatakan berhasil dari proses apabila peserta didik terlibat secara aktif baik fisik maupun mental dalam proses belajar mengajar

\section{Kordinasi dan Kerjasama Dengan Stake Holder Pendidikan di MI Najatus Salikin}

Stakeholder pendidikan di Madrasah Ibtidaiyah Najatus Salikin dibagi dalam 3 kategori utama, yaitu:

a. Sekolah, termasuk di dalamnya adalah para guru, kepala sekolah, murid dan pegawai tata usaha.

b. Pemerintah, diwakili oleh para pengawas, penilik, departemen agama, pemda setempat, sampai menteri pendidikan nasional.

c. Masyarakat, merupakan sekelompok individu yang berkepentingan dengan pendidikan seperti orangtua murid, pengamat dan ahli pendidikan, lembaga swadaya masyarakat, toko buku, kontraktor pembangunan sekolah, penerbit buku, penyedia alat pendidikan, dan lain-lain.

Parastakeholdertersebutdiatasmerupakan unsur penting yang tidak dapat ditinggal begitu saja, hal ini membuktikan bahwa pihak madrasah senatiasa menjaga hubungan baik dengan organisasi ekstern atau pelaku usaha tertentu melalui beberapa bentuk kerjasama yang telah dijelaskan pada bab sebelumnya, guna mendukung keberlangsungan suatu kegiatan pembelajaran. Inisiatif yang dilakukan pihak madrasah tersebut juga selaras dalam salah satu dari tiga kajian keagamaan bahwa setiap manusia hendaklah menyeimbangkan antara habluminannas, habluminallah, dan habluminal'alam.

Tiap orang berbeda kebutuhan dan keinginannya. Mereka bekerja pada suatu badan dengan harapan, salah satu kebutuhan/ 
keinginannya akan terpenuhi, sehingga mereka mendapat kepuasan.

Untuk menjalin kerjasama yang seefektifefektifnya antara individu-individu tadi, sehingga badan itu memperoleh hasil yang produktif sebagaimana yang diharapkan, perlu sekali untuk diciptakannya suasana/ lingkungan kerja yang memotivasi dan dapat memberi kepuasan secara keseluruhan pada orang-orang tersebut. ${ }^{10}$

Prinsip-Prinsip supervise yang dilakukan di MI Najatus Salikin terkait dengan Human Relations meliputi:

a. Importance of the Indifidual (Pentingnya Individu). Seperti sudah diketahui tiap orang harus diperlakukan sebagai individu. Menurut davis, tindakan suatu badan harus memperhitungkan perasaan pegawai, mengakui dan memperhatikan kepentingannya.

b. Mutual Acceptance (Saling Menerima). Pemimpin, yang dipimpin dan organisasi suatu badan harus bersatu. Mereka satu sama lain harus saling menerima sebagai individu dan sebagai kelompok. Harus saling menghormati dan menghargai tugas dan kewajiban masing-masing.

c. Common Interest (Kepentingan Bersama). Pemimpin, yang dipimpin, dan organisasi buruh satu sama lainnya terikat oleh kepentingan bersama. Karena mereka bersatu mereka mampu mencapai sukses dalam pekerjaannya dan terjaminnya kebutuhan tiap individu tergantung pada sukses itu.

d. Open Communication (Komunikasi Terbuka). Berterus terang mengenai ide, perasaan, dan mengenai segala sesuatu yang menyangkut kepentingan bersama. Komunikasi yang sifatnya terbuka akan menimbulkan pengertian yang lebih baik dan menghasilkan keputusan-keputusan yang lebih tepat.

e. Partisipasi Pegawai. Hasil-hasil yang efisien disebabkan karena adanya keseimbangan dalam pendangan-pandangan dan karena

10 Oemi Abdurrachman, (1968) Dasar - Dasar Public Relations, PT.Citra Aditya Bakti, Bandung, hlm, 79-81. segala problema yang dihadapi dan dipecahkan bersama-sama. ${ }^{11}$

Kebijakan yang melibatkan orang lain ini sesuai dengan konsep dalam kajian ilmu sosiologi yang disebut sebagai "hakikat manusia sebagai makhluk sosial" yaitu tidak mungkin seseorang dapat mencukupi kebutuhannya sendiri tanpa melibatkan orang lain. ${ }^{12}$

\section{Pembangunan Sarana dan Prasarana di MI Najatus Salikin}

Dalam hal pengadaan sarana dan prasarana guna mendukung pembelajaran, kepala madrasah tidak jarang mengajukan proposal permohonan bantuan dana rehap baik kepada instansi maupun perorangan, ini sesuai dengan konsep manajemen aliran perilaku atau biasa diistilahkan dengan aliran hubungan manusia yang memusatkan segala kajian kepada aspek manusia serta perlunya memahami karakter manusia tersebut. Aliran Perilaku ini diprakarsai oleh Henry (18611919) seorang sosialis yang menggunakan disiplin ilmu sosiologi dan psikologi dalam penerapannya. Teori ini menyadari betapa pentingnya hubungan antar personal dalam suatu organisasi. ${ }^{13}$

Sehubungan dengan pembangunan sarana dan prasarana, barnawi dan arifin mengemukakan bahwa dalam menunjang terselenggaranya suatu pembelajaran membutuhkan suatu pengelolaan tersendiri atau disebut dengan instilah manajemen sarana dan prasarana yangmana meliputi langkah - langkah seperti: Perencanaan, Pengadaan, Pengaturan, Penggunaan, Penghapusan.

Penanggung jawab manajemen sarana dan prasarana ialah kepala sekolah. Selaku manajer, kepala sekolah harus menerapkan kaidah-kaidah manajemen dalam mengelola sarana dan prasarana agar pemanfaatannya

11 Ibid, hlm, 85-86.

12 Djamaludin Ancok (2012), Psikologi Kepemimpinan \& Inovasi, Erlangga, Jakarta, hlm 50.

13 Wina Sanjaya (2012), Media Komunikasi Pembelajaran, Kencana Prenada Media Group, Jakarta, hlm. 20. 
benar-benar tepat guna dan tepat sasaran. ${ }^{14}$

\section{Manfaat dan Hasil Supervisi Kelembagaan Di Mi Najatus Salikin Kedungsari Kecamatan Tarokan Kabupaten Kediri}

1. Membantu kepala sekolah dan para guru mengadakan diagnosis secara kritis terhadap aktivitas - aktivitasnya dan kesulitan dalam pembelajaran dikelas.

2. Mengetahui kelemahan atau kekurangan dan kelebihan yang dimiliki lembaga tersebut.

3. Mengadakan tindaklanjut perbaikan jika dijumpai atau ditemukan suatu kekurangan baik personal maupun kelompok dalam lembaga tersebut.

4. Bagi kepala madrasah berguna untuk mengetahui kinerja para guru yang menjadi tenaga pendidik di lembaga tersebut. Apakah seorang guru perlu di rekomendasikan untuk mengikuti diklat atau seminar tentang metode atau cara mengajar yang sesuai dalam mengelola suatu kelas pembelajaran.

5. Menganalisa kesulitan - kesulitan atau permasalahan yang terjadi saat proses pembelajaran sedang berlangsung secara bersama dan bermusyawarah.

6. Membantu guru dalam membimbing pengalaman belajar peserta didik.

7. Membantu guru dalam menggunakan alat pelajaran dan metode atau strategi belajar yang sesuai dengan kondisi dilapangan.

\section{Kesimpulan}

Akhirnya penelitian ini dapat disimpulkan sebagai berikut:

1. Pelaksanaan supervisi kelembagaan di MI Najatus Salikin oleh kepala madrasah dilaksanakan secara berkala yakni bisa tengah dan akhir semester, tetapi di saat tertentu juga bisa mensupervisi seorang guru selama beberapa kali dalam seminggu dengan cara mengunjungi kelas pada

14 Barnawi, M. Arifin (2012), Majemen Sarana \& Prasarana Sekolah, Ar-Ruzz Media, Jogjakarta, hlm, 40-41. saat proses pembelajaran berlangsung. mengadakan percakapan pribadi dengan seorang guru. Ini beliau prioritaskan bagi tenaga pendidik yang masih baru dalam lembaga tersebut, sehingga seluruh guru dalam lembaga tersebut dapat selalu melaksanakan kelas pembelajaran yang sesuai dengan arahan kepala madrasah. Menurut beliau, kegiatan supervisi yang dilakukan terhadap para guru yakni dengan cara merekomendasikan guru untuk diikutkan seminar atau pelatihan-pelatihan tentang metode pembelajaran yang dapat diterapkan dikemudian hari. Biasanya acara-acara tersebut diadakan oleh dinas pada tingkat kabupaten/ kota maupun propinsi sebanyak 1 sampai 2 kali selama setahun.

2. Dengan diterapkannya supervisi kelembagaan oleh kepala madrasah ini, sedikit demi sedikit berdampak pada tingkat komunikasi antara kepala madrasah dengan para guru senantiasa lebih terjalin, kemudian antara kepala madrasah dengan komite juga lebih intensif daripada sebelum diberlakukannya supervisi tersebut, begitu juga dengan para staf administrasi madrasah. Berawal dari perbaikan hubungan komunikasi kemudian secara tidak langsung berdampak pada peningkatan kinerja yang lebih baik kedepan.

3. Faktor-faktor yang mendukung supervisi kelembagaan di MI Najatus Salikin antara lain: a) Tingkat sumber daya manusia atau kemampuan dari masing-masing dari individu. ) Terjalinnya komunikasi antar personal dalam kepengurusan madrasah. c) Kebijakan-kebijakan dari kepala madrasah yang bersifat membangun. Sementara faktor yang menghambat pelaksanaan supervisi kelembagaan di MI Najatus Salikin meliputi: a) Kurangnya terjalin komunikasi antar lini personal dalam lembaga 
tersebut.b) Kurang cakapnya seseorang dalam mengelola, mengorganisir dan mengembangkan kemampuan baik secara individu maupun kepemimpinan seorang kepala madrasah.

\section{DAFTAR PUSTAKA}

Abdurrachman Oemi. (1968) Dasar - Dasar Public Relations. Bandung: PT. Citra Aditya Bakti.

Ancok Djamaludin. (2012) Psikologi Kepemimpinan \& Inovasi. Jakarta: Erlangga.

Arikunto S. (2004) Dasar - Dasar Supervisi buku pegangan kuliah: Jakarta PT RINEKA CIPTA.

Arikunto S. (2004) Dasar-Dasar Supervisi: PT Rineka Cipta. Jakarta.

Arikunto S. dan Lia Yuliana. (2008) Manajemen Pendidikan : Yogyakarta: Aditya Media,

Badrus M. Kepala MI Najatus Salikin, Kedungsari Tarokan Kediri, 18-062016

Barnawi dan Arifin, M. (2012) mananemen sarana dan prasarana sekolah. Yogyakarta : Ar-Ruzz Media.

Creswell, J.W. (2010) RESEARCH DESIGN Pendekatan Kulitatif, Kuantitatif, Dan Metode Campuran: Yogyakarta: Pustaka Belajar,

Hamalik Oemar. (2003) Kurikulum dan Pembelajaran : Jakarta: PT. Bumi Aksara.

Hasbullah. (1999) Dasar-Dasar Ilmu Pendidikan: Jakarta: PT. Raja Grafindo Persada.

Haryati Nik. (2011) Pengembangan Kurikulum Pendidikan Agama Islam. Bandung: Alfabeta.

http://addhitya25.blogspot.co.id/2013/05/ v-behaviorurldefaultvmlo.html, diakses tanggal 07-04-2016.

http://agoeztzhoe.blogspot. co.id/2012/04/160-tanya-jawabtentang-supervisi.html, diakses 2305-2016.

http://amazingchems.blogspot. co.id/2012/11/perkembangankonsep-supervisi-dalam 961.html, diakses tanggal 20-04-2016.

http://edinasirun76.blogspot. co.id/2011/03/pendekatan-danteknik-supervisi.html, diakses tanggal 19-07-2016.

http://pujakesuma-igmafazizah. blogspot.co.id/2011/10/prosedurpengembangan-sistem-supervisi. html, diakses tanggal 14-03-2016.

http://riosaputraoke.blogspot. co.id/2010/12/faktor-faktor-yangmempengaruhi.html, diakses tanggal 24-04-2016.

http://staff.uny.ac.id/sites/default/ files/10\%20Supervisi $\% 20$ Pendidikan.pdf, diakses tanggal 0704-2016.

http://tatafisika.blogspot.co.id/2013/01/ supervisi-pendidikan.html, diakses tanggal, 23-05-2016.

http://www.uin-malang.ac.id/r/101001/ triangulasi-dalam-penelitiankualitatif.html, diakses 20-01-2016.

http://zuherli.blogspot.co.id/2013/08/makalahsupervisi-pendidikan.html, diakses tanggal 24-04-2016.

Jasmani, Syaiful M. (2013) Supervisi Pendidikan Terobosan Baru Dalam Peningkatan Kinerja Pengawas Sekolah Dan Guru: Jogjakarta: ArRuzz media,

Kisbiyanto. (2008) Supervisi Pendidikan: STAIN Kudus, Kudus.

Made Pidarta. (2009) Supervisi Pendidikan 
Kontekstual: Jakarta; Rineka Cipta,

Margono. S. (2009) Metode Penelitian Pendidikan: Rineka Cipta, Jakarta

Masaong. A.K. (2013) Supervisi Pembelajaran Dan Pengembangan Kapasitas Guru. Bandung: Alfabeta.

Moleong, L.J. (1995) Metode Penelitian Kualitatif. Bandung: Remaja Rosdakarya,

Mufidah, Luluk Nur. (2009) SupervisiPendidikan: Yogyakarta: Teras..

Muslim Sri Banun, (2009) Supervisi Pendidikan Meningkatkan Kualitas Profesionalisme Guru:Bandung:Alfabeta

Nadhirin. (2009) Supervisi Pendidikan Integratif Berbasis Budaya, STAIN Kudus.

Nasdan Tonny, F. (2014) Pengembangan Masyarakat. Jakarta: Yayasan Pustaka Obor Indonesia.

Nazir M. (1998) Strategi Penelitian, Ghalia Indonesia, Jakarta.

Observasi, MI Najatus Salikin, Kedungsari Tarokan Kediri, 12-05-2016.

Purwanto,Ngalim. (1987) Administrasi dan Supervisi Pendidikan: PT Bandung: Remaja Rosda Karya,

Pusat Kurikulum Badan Penelitian dan Pengembangan Depdiknas. (2001) Kurikulum Berbasis Kompetensi Kebijakan Umum Pendidikan Dasar dan Menengah, Jakarta: Depdiknas.

Ratal, Wirjasantosa. (1984) Supervisi Pendidikan Olah Raga: Jakarta: ULPress.

Rukmana N. (2007) etika kepemimpinan perspektif agama dan moral. Alfabeta. Bandung.

Sagala Syaiful. (2007) Konsep dan Makna Pembelajaran: Alfabeta. Bandung.

Sanjaya Wina. (2012) Media Komunikasi Pembelajaran. Kencana Prenada Media Group. Jakarta.
Suarnaya, I P. (2012) Manajemen Pendidikan Suatu Pengantar Praktis. Gunung Samudera. Malang.

Suhardan dadang. (2010) Supervisi Profesional, (Layanan dalam Meningkatkan Mutu Pembelajaran di Era Otonomi Daerah). Alfabeta, Bandung.

Sukandarrumidi. (2004) Metodologi Penelitian PetunjukPraktisUntuk Peneliti Pemula: Gadjah Mada University Press, Yogyakarta.

Susilo Joko. M. (2007) Kurikulum Tingkat Satuan Pendidikan, Majemen Pelaksanaan Dan Kesiapan Sekolah Menyongsongnya. Pustaka Pelajar. Yogyakarta.

Susilo Suko. (2011) Dasar - Dasar Kepemimpinan, Surabaya: Jenggala Pustaka Utama

Usman,uzer. (2006) Menjadi Guru Profesional: Bandung: Remaja Rosdakarya 